\title{
KUALITAS TES KOMPETENSI TUKANG ACI DAN PLESTERAN BERDASARKAN KKNI
}

\author{
I. Maulana, R. Arthur, Daryati \\ Fakultas Teknik, Universitas Negeri Jakarta \\ Email: Ivan_sipil14@mahasiswa.ac.id, arthur@unj.ac.id, daryati_sr@unj.ac.id
}

\begin{abstract}
ABSTRAK
Penguasaan kompetensi merupakan prioritas yang harus dimiliki oleh setiap tukang (pekerja terampil) dalam melaksanakan pekerjaan, untuk mengukurnya diperlukan sebuah instrumen. Instrumen harus bisa menjadi acuan penilaian kompetensi tukang sesuai dengan standar yang ada dan kebutuhan di lapangan dalam upaya menciptakan tukang yang berkualitas dan mampu beradaptasi dengan perkembangan industri saat ini. Penelitian ini bertujuan untuk mengetahui apakah instrumen pekerjaan plesteran yang berlaku telah sesuai dengan standar dan kebutuhan lapangan. Rancangan penelitian menggunakan pendekatan kualitatif dengan teknik pengumpulan data berupa kuesioner yang ditujukan ke panel ahli dalam memperoleh justifikasi terhadap instrumen yang sudah ada. Dari hasil penelitian berdasarkan justifikasi ahli diperoleh bahwa beberapa butir pekerjaan tidak sesuai dengan implementasi di lapangan saat ini, serta penggunaan metode penilaian yang digunakan kurang tepat pada instrumen yang ada. Manfaat penelitian ini diharapkan dapat menjadi referensi dalam mengembangkan instrumen pekerjaan plesteran.
\end{abstract}

Kata kunci: kompetensi, instrumen, plesteran

\begin{abstract}
Mastery of competence is a priority that must be owned by every worker in carrying out work, to measure it an instrument is needed. Instruments must be able to become a reference for the assessment of worker competencies in accordance with existing standards and needs in industry, in an effort to create worker who is qualified and able to adapt to current industrial developments. This study aims to determine whether the plastering work instruments that apply are in accordance with the standards and needs of industry. The study design used a quantitative-qualitative approach with data collection techniques in the form of questionnaires addressed to the expert panel in obtaining judgement for existing instruments. From the results of the research based on expert judgement it was found that some work items were not in accordance with the current implementation in the construction, and the use of the assessment method used was not appropriate for the existing instruments. The benefits of this research are expected to be a reference in developing plastering work instruments.
\end{abstract}

Keywords : competence, instrument, plastering

\section{PENDAHULUAN}

Kesiapan sumber daya manusia (SDM) yang mampu memahami serta menguasai kompetensi kerja menjadi salah satu perhatian saat ini dalam upaya menciptakan pelaksanaan konstruksi yang aman dan berkualitas [1], di sisi lain Kebutuhan SDM kompeten di Indonesia pun sangat nyata [2]. Menurut Becker dan Ullrich [3] "Competency refers to an individual's knowledge, skill, ability or personality characteristic that directly influence job performance". Senada dengan itu, Utomo [4] menyatakan bahwa kompetensi kerja merupakan kemampuan individu mencakup aspek keterampilan (skills) serta sikap kerja (work attitude) yang sesuai dengan standar yang ditetapkan. Jadi, setiap tenaga kerja harus memiliki kesadaran akan pentingnya kompetensi [5], sebab hal ini akan tercermin dari cara bagaimana mereka melaksanakan dan menyikapi pekerjaan tersebut. Hubungan tersebut dapat dilihat dalam bagan berikut: 


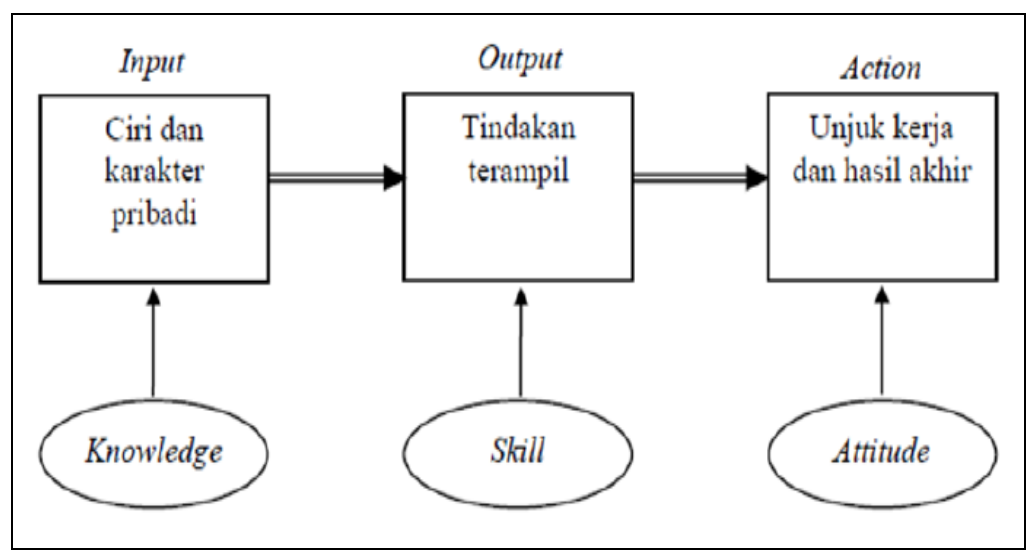

Gambar 1. Karakteristik dasar Kompetensi Sumber : [5]

Hubungan kompetensi dengan kinerja yang saling mempengaruhi seperti terlihat pada gambar di atas. Penguasaan aspek pengetahuan akan memberikan dampak kepada ciri dan karakter seseorang, dan jika disejajarkan dengan keterampilan yang dimiliki akan menghasilkan output berupa tindakan terampil dan perlunya juga penerapan sikap kerja yang baik. Oleh karena itu, setiap pekerja konstruksi diwajibkan memahami dan mengimplementasikan standar kompetensi yang ada, karena akan memberikan pengaruh berarti bagi pelaksanaannya, hasil kerja serta achievement yang pantas diperoleh. Standar kerja ini tertuang dalam pembukuan Standar Kompetensi Kerja Nasional Indonesia (SKKNI) yang mengandung rumusan kemampuan kerja yang relevan dengan pelaksanaan serta syarat jabatan yang ditetapkan oleh pemerintah.

Namun, kenyataannya masih banyak tenaga kerja "belum matang" dengan penguasaan kompetensi yang masih minim. Data Badan Pusat Statistik (BPS) menunjukkan di akhir tahun 2017 sebanyak 5,6 juta tenaga kerja konstruksi hanya berstatus pendidikan Sekolah Dasar (SD) dan Sekolah Lanjutan Tingkat Pertama (SLTP), bahkan 8\%-nya tidak atau belum tamat SD. Menurut [6] rendahnya tingkat pendidikan dan kesadaran akan kompetensi menjadi titik kritis kualitas SDM konstruksi, khususnya tenaga terampil. Tenaga terampil adalah operator yang menangani langsung suatu pekerjaan tertentu, seperti drafter, surveyor, dan juga tukang [5]. Lulusan Sekolah Menengah Kejuruan (SMK) pun dapat digolongkan sebagai tenaga terampil. Sehingga, tenaga kerja layaknya tukang ataupun drafter yang dibutuhkan lapangan sudah seharusnya berasal dari tingkat pendidikan minimal SMK, kualifikasinya dapat dilihat pada gambar berikut:

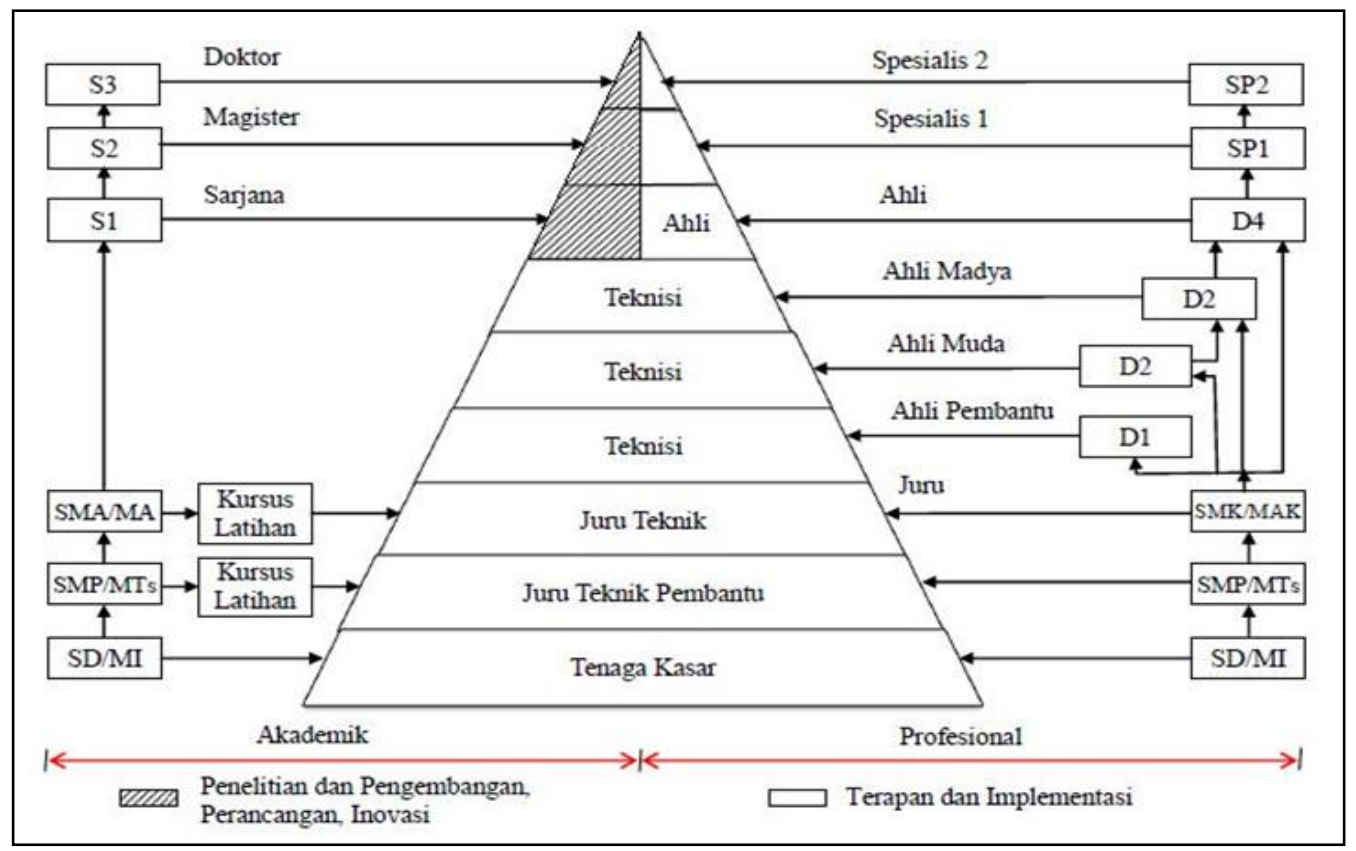

Gambar 2. Piramida ketenagakerjaan dan jenjang pendidikan sekolah

Sumber: [5] 
Dilihat dari gambar tersebut, tidak dapat dipungkiri jika SMK masih masuk kedalam golongan "juru teknik" atau tenaga terampil. Namun, secara garis besar kompetensi dasar yang diperoleh dari SMK memang telah mempersiapkan peserta didik untuk memiliki pekerjaan dengan keahlian terapan tertentu. Hal ini didukung oleh [8] yang berpendapat SMK memang dirancang untuk mengembangkan keterampilan dan kebiasaan kerja yang dibutuhkan oleh lulusannya dalam memasuki lapangan kerja. Serta pendapat yang sama juga dikemukakan [9] bahwa dengan kompetensi yang diperoleh selama masa akademik, lulusan SMK harus adaptif terhadap perubahan dan difusi teknologi saat ini.

Kesimpulan yang dapat diambil dari uraian di atas, bahwa tenaga terampil seperti tukang sudah seharusnya memiliki kompetensi setara dengan apa yang diajarkan di SMK dan kebutuhan industri saat ini. SDM yang terlanjur menjadi tukang pun sudah seharusnya mendapatkan jaminan kompetensi yang sesuai. Oleh karena itu, dalam mewujudkan hal tersebut perlu adanya dukungan dalam berbagai aspek, salah satunya dengan adanya pedoman kompetensi seperti instrumen yang dapat menjadi acuan pengukuran kompetensi yang dibutuhkan tukang serta mencakup standar kompetensi yang ada dan juga relevansi di lapangan.

Instrumen adalah alat bantu untuk mengumpulkan data guna mengukur ketercapaian kompetensi seseorang [10]. Instrumen diperlukan dalam mengukur tingkat penguasaan tenaga kerja melalui proses assessment atau penilaian [11]. Instrumen penilaian adalah seperangkat alat bantu dalam mengumpulkan data dengan tujuan mengukur ketercapaian kompetensi [12] dalam hal ini adalah pekerja terampil plesteran. Teknik penilaian tidak lepas dari suatu instrumen yang digunakan dan aspek yang dinilai dalam rangka mengumpulkan informasi keberhasilan pekerja sesuai dengan kompetensi yang perlu dikuasai serta diterapkan. Salah satu pekerjaan yang akan menjadi fokus penelitian adalah pekerjaan plesteran.

Tahap finishing merupakan pekerjaan penyelesaian atau penyempurnaan dalam pelaksanaan konstruksi setalah rampungnya bagian struktur bangunan. Tahap ini mencakup pekerjaan pemasangan plafon, pemasangan penutup lantai, plesteran-acian, dan pengecatan [13]. Menurut Arthur [14] dan Mubarok [15] plesteran menjadi fungsi penting dalam suatu bangunan karena memberikan kesan pertama kepada pengguna jasa atas kelancaran dan baik atau tidaknya kinerja pekerjaan selama pelaksanaan. Di antara hasil plesteran yang baik, memiliki ketebalan plester sesuai secara keseluruhan (rata) dan tidak adanya retak yang muncul pada permukaan. Oleh karena itu, kompetensi dalam pekerjaan plesteran perlu diperhatikan.

Penelitian ini bertujuan untuk mengetahui apakah instrumen (milik PU) yang berlaku saat ini telah mencakup standar kompetensi yang ada dan kebutuhan di lapangan dalam mengukur penguasaan kompetensi tukang plesteran. Untuk itu, perlu adanya justifikasi dari panel ahli terhadap instrumen tersebut.

\section{METODE}

Penelitian ini menggunakan pendekatan kualitatif dengan teknik pengumpulan data berupa kuesioner. Menurut [16] kuesioner bertujuan untuk mengetahui tingkat kelayakan produk serta mengetahui penilaian dari responden atau ahli dengan cara memberikan seperangkat pertanyaan tertulis untuk dijawab oleh responden tersebut. Kuesioner ini akan ditujukan kepada panel ahli dalam memperoleh expert judgement (justifikasi ahli) terhadap instrumen pekerjaan plesteran yang ada.

Kuesioner berbentuk checklist dengan tiga pilihan jawaban yakni: "sesuai", "tidak sesuai", dan "sesuai dengan perbaikan" sebagai catatan dan masukan dari ahli terhadap butir-butir pekerjaan yang diamati. Ahli akan terdiri dari tiga orang, dengan kualifikasi satu sebagai ahli instrumen dan dua ahli sebagai penilai konten dan materi pekerjaan terkait. Sebagai ahli instrumen dipilih seseorang dengan kualifikasi keahlian pada penelitian dan evaluasi pendidikan yakni Andi Muhammad Ishak, M.Pd, sebagai ahli materi pertama Tri Kabul Santoso dengan kualifikasi keahlian sebagai Supervisor Finishing selama lebih dari 8 tahun di kontraktor swasta, dan ahli materi kedua Suparno, S.Pd dengan kualifikasi sebagai guru dalam bidang dasar-dasar konstruksi bangunan di salah satu SMK negeri di Jakarta.

Penelitian ini juga dilengkapi dengan analisa komparasi untuk instrumen pekerjaan plesteran yang saat ini berlaku, terhadap kompetensi-kompetensi dasar yang ada di SMK bangunan "KI \& KD Teknologi dan Rekayasa" pada bagian Konstruksi Gedung, Sanitas, dan Perawatan. Hasil komparasi akan dijadikan pendukung dengan pendapat yang telah diberikan oleh ahli materi. 


\section{HASIL DAN PEMBAHASAN}

Dari hasil penelitian yang diperoleh, ahli instrumen menyimpulkan bahwa keseluruhan instrumen masih dalam kriteria sesuai, namun saran diberikan pada bagian performance test yang sebaiknya tidak menggunakan skala Guttman. Skala ini digunakan hanya jika ingin mendapatkan jawaban tegas dengan opsi antara "Ya" atau "Tidak" , sehingga beliau menyarankan penggunaan rating scale karena akan memberikan penilaian objektif dan penjabaran kriteria yang jelas, contohnya rubrik. Dari sisi materi dan isi, judge diberikan oleh salah satu ahli mengenai beberapa butir pekerjaan tidak relevan dengan kenyataan di lapangan saat ini, seperti pada langit-langit tidak ada namanya plesteran (bahan plester: semen, pasir), saat ini langit-langit hanya di finish dengan lapisan skimcoat atau patching saja, dan juga lantai tidak diplester, lantai hanya di finish dengan sebutan screeding, yakni sebagai elevasi dan perataan lantai. Sedangkan ahli materi kedua menambahkan jika tidak hanya APD (Alat Pelindung Diri) yang diperlukan, tetapi juga kondisi dan kebersihan lingkungan menjadi prosedur dalam persiapan pekerjaan.

Mengenai pendapat pertama dari Andi Muhammad Ishak (ahli instrumen), hal yang terpenting dalam mengukur keterampilan yang menjadi "kekuatan utama" tenaga terampil adalah menggunakan performance test. Dikutip dari Arini [17] "Performance test usually a test requiring manipulatory or motor response as in a test of manual dexterity", atau dalam bidang-bidang keterampilan, penggunaan tes performance adalah teknik pengukuran yang paling tepat. Menurut Linn \& Gronlund [18] kelebihan menggunakan performance test adalah bahwa performance test mampu: (1) mengkomunikasikan secara jelas instruksional yang melibatkan kinerja kompleks dalam lingkungan sebenarnya; (2) mengukur hasil belajar yang tidak dapat diukur oleh alat ukur lainnya; dan (3) memberikan alat penilaian proses produk. Oleh sebab itu, beliau menyarankan untuk mengukur keterampilan tukang sebaiknya menggunakan performance test karena dapat mengukur secara jelas bagaimana tukang menggunakan alat dan mesin plester atau melaksanakan plesteran dinding; yang melibatkan kinerja kompleks dengan lingkungan sebenarnya.

Ishak juga menambahkan untuk menggunakan rubrik sebagai pedoman penialaian. Rubrik membuat daftar karakteristik yang diinginkan dan yang perlu ditunjukkan dalam suatu pekerjaan, disertai panduan mengevaluasi masing-masing karakteristik tersebut [19]. Hal senada juga disampaikan [20] bahwa manfaat penggunaan rubrik adalah: (1) menjadi pedoman penilaian yang objektif dan konsisten dengan kriteria yang jelas; (2) memberikan informasi bobot penilaian pada tiap tingkatan kemampuan; dan juga (3) umpan balik terhadap mutu pekerjaan pesertanya. Penskoran dalam membuat rubrik juga dapat mengacu pada template dari Mertler berikut:

Tabel 1. Template Assesment Rubric

\begin{tabular}{cl}
\hline Skor & \multicolumn{1}{c}{ Deskripsi } \\
\hline 5 & $\begin{array}{l}\text { Memperlihatkan pemahaman yang lengkap } \\
\text { tentang permasalahannya/ seluruh persyaratan } \\
\text { tugas dimasukkan ke dalam respons }\end{array}$ \\
\hline 4 & $\begin{array}{l}\text { Memperlihatkan pemahaman yang cukup } \\
\text { tentang permasalahannya/ seluruh persyaratan } \\
\text { tugas dimasukkan ke dalam respons }\end{array}$ \\
\hline 3 & $\begin{array}{l}\text { Memperlihatkan pemahaman parsial tentang } \\
\text { pemahamannya/ kebanyakan persyaratan tugas } \\
\text { dimasukkan ke dalam respons }\end{array}$ \\
\hline 2 & $\begin{array}{l}\text { Memperlihatkan pemahaman terbatas tentang } \\
\text { permasalahannya/ banyak persyaratan tidak } \\
\text { tampak dalam respons }\end{array}$ \\
\hline 1 & $\begin{array}{l}\text { Memperlihatkan sama sekali tidak memahami } \\
\text { permasalahannya }\end{array}$ \\
\hline
\end{tabular}

Seperti yang terlihat pada tabel, rubrik menggunakan sistim penilaian yang menyediakan deskripsi skoring yang spesifik dengan tingkatan atau level yang menunjukkan angka pencapaian yang diperoleh dengan kesesuaian dalam deskripsi atau pedoman penskoran, yang disebut rating scale. Rating scale adalah penilaian dari pengumpulan data berupa data kuantitatif (angka) yang diterjemahkan ke dalam pengertian kualitatif [21]. Pendapat sama juga disampaikan bahwa rating scale adalah alat pengukuran yang menggunakan suatu prosedur terstruktur untuk memperoleh informasi berisikan seperangkat pernyataan tentang karakteristik atau kualitas dari sesuai yang akan 
diukur. Penggunaannya pada instrumen pekerjaan plesteran akan memudahkan proses penilaian oleh asesor, serta pencapaian kompetensi tukang sendiri dapat dilihat dari peroleh skor yang dicapai.

Tri Kabul Santoso (ahli materi pertama) memiliki kualifikasi sebagai supervisor finishing yang telah berkecimpung di dunia konstruksi gedung selama 8 tahun. Kabul memberikan banyak masukan yang berarti dalam segi penilaian materi dan isi terhadap butir pekerjaan ini. Butir pekerjaan yang tidak sesuai ini dikarenakan sudah tidak dilakukan lagi atau memang tidak diterapkan pada konstruksi gedung, sebut saja langit-langit; bidang ini tidak diplester karena biasanya permintaan dari owner sendiri untuk langit-langit dibuat ter-expose (terbuka), dan kebanyakan langit-langit hanya di finish dengan pemberian lapisan skimcoat atau patching saja. Hal lainnya yakni bidang lantai yang saat ini juga kebanyakan tidak di plester. Permukaan lantai hanya mengalami finishing yang disebut screeding sebagai elevasi lantai dan perataan permukaan, karena bila diplester permukaan lantai akan cepat retak atau bahkan rusak.

Tambahan lain yang dipaparkan beliau adalah prosedur-prosedur pada pekerjaan plesteran memang perlu diperhatikan oleh tukang, walaupun pekerjaan ini tidak terlalu riskan seperti pengerjaan tulangan atau pengerjaan penutup dan rangka atap. APD menjadi prioritas utama yang harus dipenuhi dalam persiapan pekerjaan yang telah diterapkan pada proyek-proyek besar saat ini, untuk itu penerapan kompetensi mengenai prosedur lapangan pun harus dimiliki oleh tukang plesteran.

Sama halnya dengan pendapat terakhir di atas, Suparno (ahli materi kedua) berpendapat demikian juga. Beliau yang berprofesi sebagai guru dasar-dasar konstruksi bangunan di SMK bangunan ini sangat tahu bagaimana perbandingan kompetensi di lapangan saat ini dengan kompetensi dasar (KD) yang diajarkan di SMK bangunan. Penerapan kompetensi di SMK bangunan tidak hanya mengutamakan "mengerjakan" atau "membuat" saja, tapi prosedur-prosedur sesuai ketentuan kerja juga perlu diterapkan dalam diri peserta didik saat pelaksanaan di lapangan. Contoh justifikasi yang dipaparkan Suparno adalah perbedaan penerapan keselamatan, pada KD (Kompetensi Dasar) di SMK, keselamatan kerja ditekankan dengan kalimat "Menerapkan prosedur Kesehatan, Keselamatan Kerja dan Lingkungan Hidup (K3LH) dalam pelaksanaan konstruksi bangunan gedung" yang berarti tidak hanya atribut keselamatan saja namun kondisi dan kebersihan lingkungan kerja perlu diperhatikan. Tambahan lain dari beliau, tukang seharusnya dapat membuat laporan kegiatan sederhana mengenai volume pekerjaan dan kebutuhan material dan membaca gambar kerja. Oleh karena itu, kompetensi yang digunakan dalam mengukur kinerja tukang perlu menekankan hal-hal tersebut dalam upaya menciptakan tukang yang menguasai kompetensi sesuai dengan kebutuhan di lapangan.

Dari hasil analisa komparasi yang dilakukan dengan instrumen yang ada terhadap kompetensikompetensi dasar di SMK bangunan yang diterapkan, hanya beberapa yang memiliki kesesuaian. Tabel juga dilengkapi review ahli materi yang memberikan catatan terhadap elemen kompetensi yang ada, seperti berikut:

Tabel 2. Analisa Komparasi SKKNI dengan KD di SMK Bangunan

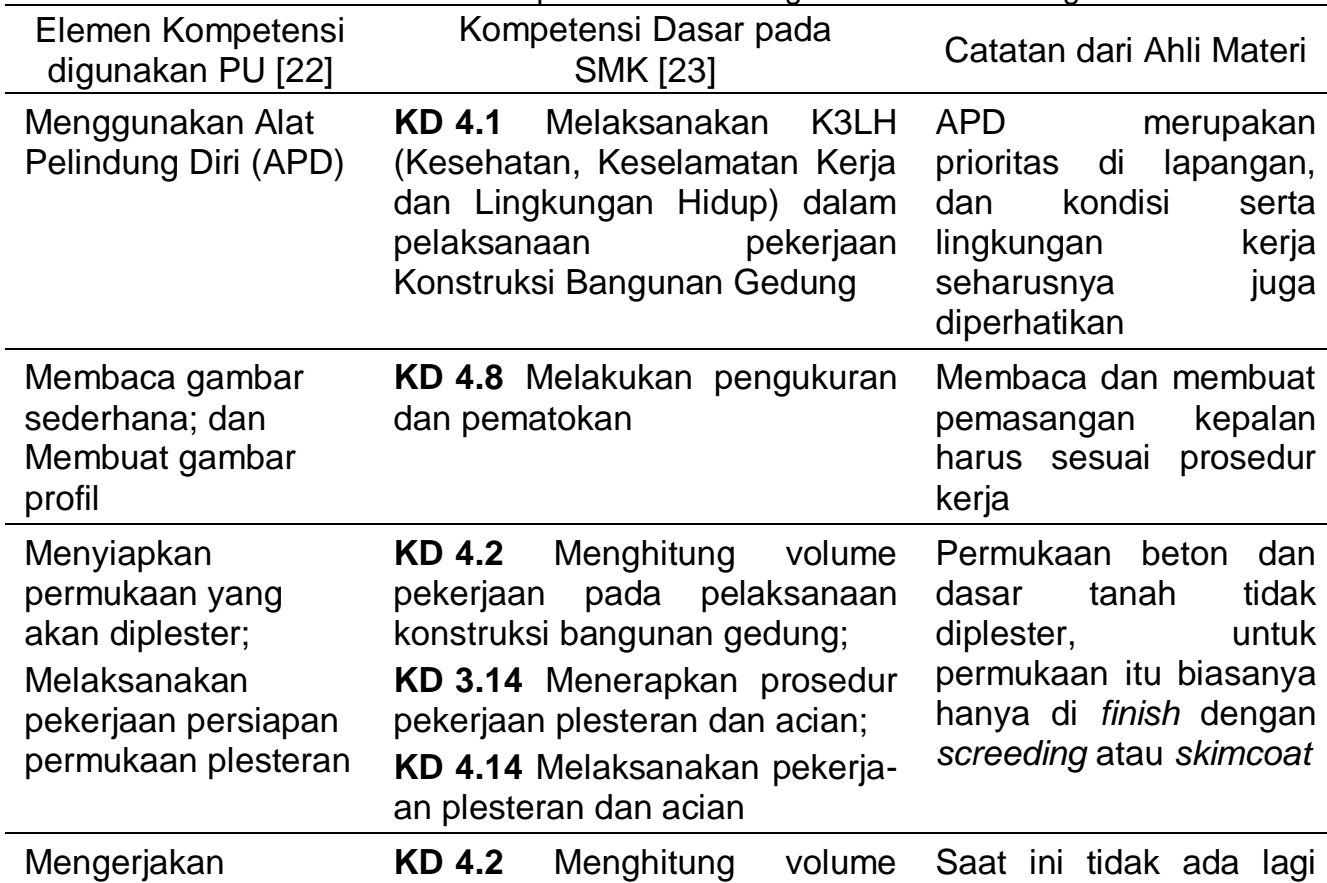


plesteran bidang dan sudut;

Melaksanakan pekerjaan plesteran;

Melaksanakan pekerjaan acian pekerjaan pada pelaksanaan konstruksi bangunan gedung;

KD 3.14 Menerapkan prosedur pekerjaan plesteran dan acian;

KD 4.14 Melaksanakan pekerjaan plesteran dan acian plesteran lantai, lantai hanya di finis atau screeding, karena cepat rusak/ retak;

Tidak ada plesteran langit-langit, hanya ada finishing berupa pelapisan skimcoat atau compound; dan

Permukaan plesteran tidak disiram karena akan mengganggu komposisi pasta acian

Menjelaskan cara menyiapkan bahan adukan; dan Menjelaskan cara membuat adukan

KD 3.3 Memahami jenis-jenis bahan yang digunakan untuk konstruksi bangunan gedung;

KD 4.3 Menyajikan jenis-jenis bahan yang digunakan untuk konstruksi bangunan gedung;

KD 4.4 Menghitung kebutuhan bahan untuk konstruksi bangunan gedung

Bahan yang digunakan biasanya sudah ada spesifikasi sesuai ketentuan. Tukang juga seharusnya dapat membuat laporan sederhana mengenai kebutuhan dan volume pekerjaan yang dicapai

Memilih alat-alat yang akan digunakan; dan KD 3.14 Menerapkan prosedur pekerjaan plesteran dan acian

Alat dijelaskan secara spesifik dan mengetahui cara perawatan alat

Memelihara dan merawat alat-alat

\begin{tabular}{llll}
\hline Mengerjakan & KD 3.14 Menerapkan prosedur & Finishing & plester tidak \\
finishing plesteran & pekerjaan plesteran dan acian; & hanya kamprotan, \\
& KD 4.14 Melaksanakan pekerja- & finishing lain seperti \\
& an plesteran dan acian & bermuka pasir dan \\
& & perataan trowel
\end{tabular}

\begin{tabular}{lllr}
\hline Memeriksa hasil & KD 4.5 Melaksanakan perawat- & Perbaikan tidak bisa \\
pekerjaan plesteran & an dan perbaikan komponen & sembarangan, plesteran \\
dan acian & lantai dan finishing & tidak rata atau \\
& & bergelembung tidak \\
& & dapat diratakan, harus \\
& dibobok/ diulang \\
\hline
\end{tabular}

Dari hasil komparasi di atas, dapat ditemui beberapa elemen kompetensi yang digunakan tidak semua sesuai atau sama dengan apa yang telah diberlakukan pada kompetensi dasar di SMK bangunan, terlihat juga beberapa kompetensi seperti "menerapkan prosedur" tidak terlalu diterapkan pada elemen kompetensi PU, sedangkan justru lebih banyak kompetensi dasar yang sesuai seperti "melaksanakan" atau "membuat" sesuatu. Hal ini membuktikan jika kompetensi yang dinilai pada kolom elemen kompetensi tersebut hanya mengandalkan keterampilan dan kemampuan dalam bekerja saja, sehingga penerapan prosedur seperti memperhatikan ketentuan kerja atau mengikuti sesuai dengan prosedur kerja tidak terlalu diprioritaskan.

Dapat dilihat juga dari pendapat ahli materi pertama yang saling berikatan dengan hasil dari komparasi yang dilakukan terhadap kompetensi dasar yang diterapkan di SMK, seperti pada elemen kompetensi di PU terdapat "Mengerjakan plesteran bidang dan sudut"; "Melaksanakan pekerjaan plesteran"; dan "Melaksanakan pekerjaan acian", kompetensi ini menuntut tukang plesteran hanya menguasai keterampilan dalam melaksanakan dan mengerjakan bentuk-bentuk bidang plesteran yang diminta, tidak ada penilaian bagaimana prosedur atau ketentuan kerja yang perlu diperhatikan oleh tukang tersebut yang menjadi "nilai tambah" dari tukang tersebut ketika mengerjakan plesteran. Sebaliknya, pada kompetensi dasar yang harus ditanamkan dan diterapkan oleh siswa SMK bangunan dalam mengerjakan finishing ini, siswa dituntut untuk memperhatikan bagaimana langkah 
awal dimulai dari persiapan, bagaimana cara memperhatikan prosedur pekerjaan, mengikuti ketentuan yang ada, dan masuk ke pelaksanaan pekerjaannya.

Sejajar dengan kompetensi PU sebelumnya, dapat terlihat jika "KD 4.2-menghitung volume pekerjaan pada pelaksanaan konstruksi bangunan gedung"; "KD 3.14-menerapkan prosedur pekerjaan plesteran dan acian"; dan "KD 4.14-melaksanakan pekerjaan plesteran dan acian", yang membuktikan jika di SMK sudah dituntut agar calon pekerja atau juru teknik (gambar 2) dapat menghitung volume pekerjaan dan juga menerapkan prosedur pekerjaan sebelum melaksanakan masuk ke pelaksanaan memlester dan mengaci. Tukang memang seharusnya sudah dapat menghitung volume pekerjaan sederhana seperti pencapaian area plesteran yang terselesaikan atau membuat data keperluan bahan dan alat yang digunakan ketika melaksanakan pekerjaan, dan seperti yang telah dipaparkan sebelumnya juga oleh pendapat ahli dua; tukang juga harus memperhatikan prosedur pekerjaan, seperti contoh bahwa perbedaan butir pekerjaan yang ada dan pelaksanaannya antara tukang yang bekerja pada lingkup kecil (low class, contoh: rumah sederhana, ruko) dengan tukang yang bekerja pada proyek/bangunan besar (mid-high class, contoh: apartemen, hotel) sangat terlihat jelas, diantaranya pada penggunaan APD dan juga material yang digunakan, salah satunya pada lingkup kecil tukang tidak terlalu memperhatikan atribut keselamatan kerja seperti safety shoes ataupun helm -walaupun mereka sedang memlester dinding luar pada lantai 3 ruko- hal ini juga disebabkan pengguna jasa tidak menyediakan APD tersebut. Sedangkan proyek mid-high, K3L (Kesehatan, Keselamatan Kerja, dan Lingkungan) menjadi prioritas yang diterapkan, selain melindungi keselamatan pekerja, memang diberlakukannya peraturan atau sanksi dalam pelanggaran K3L ini. Jadi, penerapan kompetensi yang ada pada SKKNI belum sepenuhnya diterapkan, seharusnya walaupun bekerja di bangunan level apa pun penerapan kompetensi harus tetap dijalankan oleh tukang.

Seperti yang telah dijelaskan sebelumnya pada paragraf di atas, ahli materi yang berprofesi sebagai guru dasar-dasar konstruksi bangunan tersebut sangat tahu bagaimana perbandingan kompetensi di lapangan saat ini dengan kompetensi dasar (KD) yang diajarkan di SMK bangunan. Penerapan kompetensi di SMK bangunan tidak hanya mengutamakan "mengerjakan" atau "membuat" saja, tapi prosedur-prosedur sesuai ketentuan kerja juga perlu diterapkan di diri peserta didik dalam pelaksanaan di lapangan. Contohnya yang menjadi judge dari ahli materi kedua ini adalah perbedaan penerapan keselamatan, pada KD di SMK keselamatan kerja ditekankan dengan kalimat "Menerapkan prosedur Kesehatan, Keselamatan Kerja dan Lingkungan Hidup (K3LH) dalam pelaksanaan konstruksi bangunan gedung" yang berarti tidak hanya atribut keselamatan saja tetapi kondisi dan kebersihan lingkungan kerja perlu diterapkan. Tambahan lain seperti tukang seharusnya dapat membuat laporan kegiatan sederhana mengenai volume pekerjaan dan kebutuhan material dan membaca gambar kerja. Untuk itu kompetensi yang digunakan dalam mengukur kinerja tukang perlu menekankan hal-hal tersebut dalam upaya menciptakan tukang yang menguasai kompetensi sesuai dengan kebutuhan di lapangan.

Berdasarkan pembahasan di atas, dapat ditemui jika jawaban diperoleh dari pendapat para ahli dan juga komparasi yang dilakukan memang ditemui jika kesesuaian kompetensi yang dibutuhkan oleh tukang saat ini belum maksimal, seperti pada sketsa gambar di bawah yang dibuat oleh peneliti sebagai gambaran perbandingan:

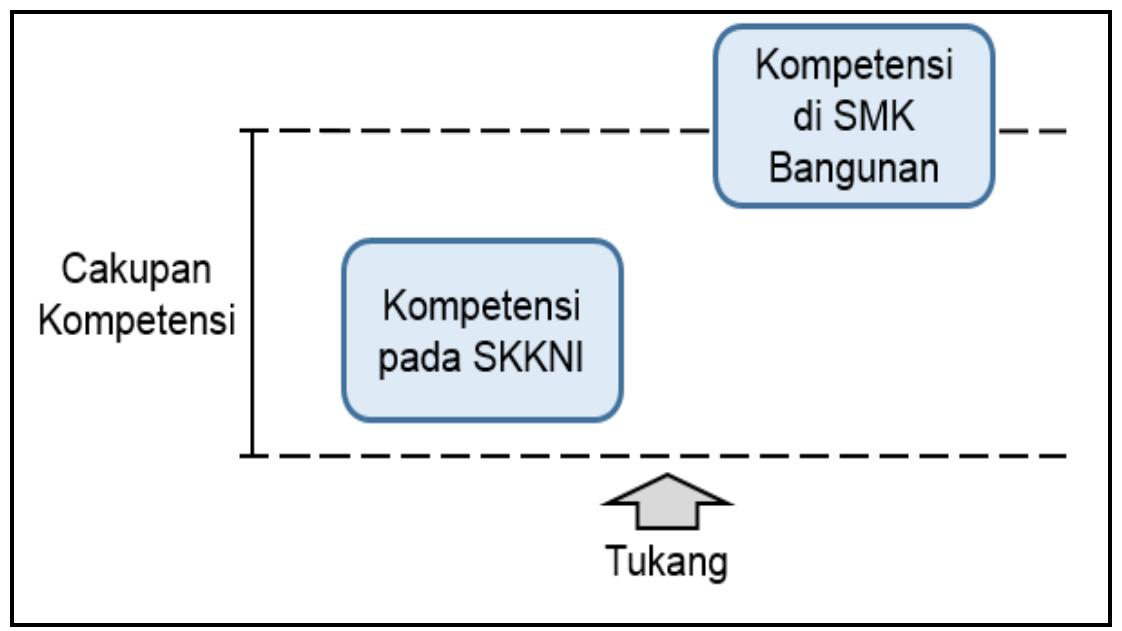

Gambar 3a. Sketsa perbandingan cakupan kompetensi yang ada 


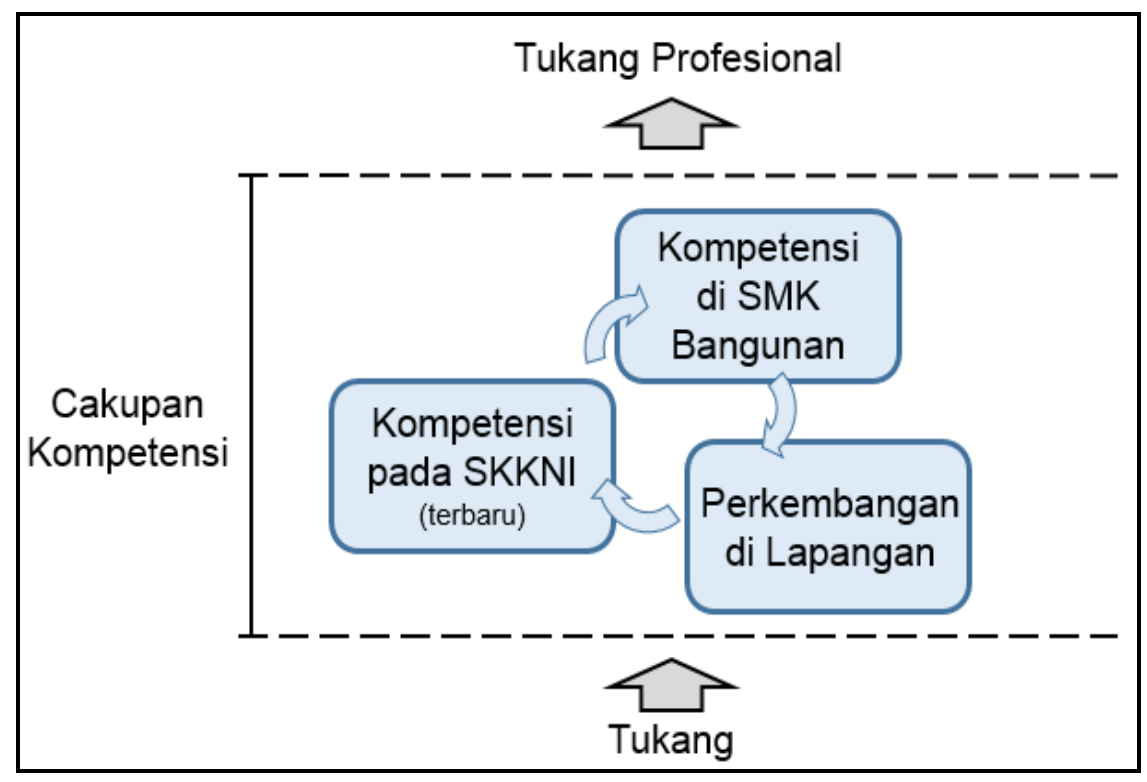

Gambar 3b. Sketsa perbandingan cakupan kompetensi yang diharapkan

Dengan tingkat pendidikan yang masih rendah dan kurangnya penguasaan kompetensi seperti yang telah dibahas di latar belakang, menjadikan tukang tidak mendapatkan keterampilan yang dibutuhkan sesuai dengan lapangan dan apa yang diperoleh oleh lulusan SMK bangunan yang menjadi standar bagaimana seharusnya tukang-tukang memiliki dan mengusai kemampuan tidak hanya mengerjakan pekerjaan plesteran dan acian saja, menggunakan alat, ataupun membuat adukan plester saja, tapi tukang perlu memperhatikan prosedur-prosedur tiap butir pekerjaan plesteran seperti persiapan pekerjaan yang tidak hanya menggunakan alat pelindung diri namun kebersihan dan kondisi bidang kerja juga perlu diperhatikan, atau prosedur bagaimana memlester yang baik dan benar dengan menggunakan alat sesuai dengan fungsi dan langkah-langkah pekerjaan serta acuan ukuran dan pemasangan yang tepat.

Kedua gambar di atas menunjukkan perbedaan yang sangat nyata antara cakupan kompetensi yang ada saat ini dan yang seharusnya diterapkan kepada tukang-tukang untuk menjadikan tukang profesional dan meningkatkan kualitas kerjanya. Cakupan kompetensi yang diharapkan seperti Gambar 3b, menunjukkan kelengkapan pengetahuan dan keterampilan yang sesuai dengan kebutuhan tukang dalam melaksanakan pekerjaan dan memperoleh hasil yang diharapkan baik pengguna jasa dan tukang itu sendiri. Perpaduan antara kompetensi pada SKKNI terbaru yang telah diwajibkan untuk dimiliki semua tenaga kerja Indonesia dan kompetensi yang diterapkan dalam kegiatan belajar mengajar di SMK agar lulusannya mempelajari langsung perkembangan teknologi dan di lapangan saat ini, menjadikan tukang-tukang yang telah lama bekerja di bidangnya ini memperoleh pengakuan kompetensi sesuai standar yang berlaku dan memperoleh pelatihan dan keterampilan seperti apa yang diperoleh lulusan SMK tersebut, sehingga tukang ini mampu bersaing dengan pekerja lainnya dan meningkatkan upah kerja atas kompetensi yang telah dikuasainya.

Oleh karena itu, langkah paling tepat yang seharusnya dilakukan adalah dengan menerapkan cakupan kompetensi untuk tukang plesteran ini dengan memasukkan SKKNI terbaru jabatan kerja tukang plesteran bangunan gedung, dan penyesuaian kompetensi-kompetensi dasar yang ada di SMK bangunan, serta bagaimana implementasi pelaksanaan pekerjaan plesteran di lapangan saat ini, seperti gambar di atas. Langkah tersebut juga sesuai dengan hasil pendapat dari ketiga ahli yang telah dilakukan dan komparasi elemen kompetensi yang dibubuhkan oleh PU terhadap penerapan kompetensi (KD) di SMK saat ini.

\section{SIMPULAN DAN SARAN}

Kesimpulan yang dapat dipetik dari hasil penelitian ini adalah instrumen pekerjaan plesteran yang digunakan sebagai acuan dalam pelaksanaan uji kompetensi tukang belum relevan dengan implementasinya di lapangan saat ini dan kompetensinya yang masih belum sama dengan yang telah di terapkan pada SMK. Penggunaan metode penilaian dalam mengukur kinerja tukang sangat harus diperhatikan untuk memberikan gambaran kepada tukang bagaimana item pekerjaan tersebut dapat dicapai dan menghasilkan tukang yang memahami kompetensi dan kemampuannya sendiri. Maka 
diharapkan adanya pengembangan instrumen untuk pedoman pekerjaan plesteran yang dapat menyesuaikan kekurangan tersebut.

Tingkat pendidikan tukang yang perlu diperhatikan dan penanaman kompetensi seperti yang telah dibahas di paragraf terakhir pembahasan, mengharuskan tukang-tukang memiliki dan mengusai kemampuan yakni tidak hanya melakukan dan mengerjakan pekerjaan plesteran-acian saja, menggunakan alat, ataupun membuat adukan plester saja, tapi tukang perlu memperhatikan prosedur-prosedur tiap item pekerjaan plesteran seperti persiapan pekerjaan yang tidak hanya menggunakan alat pelindung diri namun kebersihan dan kondisi bidang kerja juga perlu diperhatikan, atau prosedur bagaimana memlester yang baik dan benar dengan menggunakan alat sesuai dengan fungsi dan langkah-langkah pekerjaan serta acuan ukuran dan pemasangan yang tepat. Perlu adanya penambahan elemen kompetensi untuk Tukang tidak hanya memiliki keterampilan dalam mengerjakan item-item pekerjaan plesteran saja, namun ketentuan yang perlu diterapkan seperti pematokan atau pemasangan kepalan yang perlu mengikuti prosedur dan gambar kerja, atau membuat adukan dan melaksanakan plester yang tidak hanya membuat saja tapi tukang juga dapat memeriksa hasil pekerjaannya apakah telah sesuai atau belum.

\section{UCAPAN TERIMAKASIH}

Ucapan terima kasih kepada Dr. Riyan Arthur, M.Pd yang telah memberikan semangat dan banyak membantu dalam pemberian masukan, saran dan pengumpulan data-data agar penelitian ini terealisasi, dan juga kepada 3 panel ahli; Andi Muhammad Ishak, M.Pd (sebagai ahli instrumen); Tri Kabul Santoso dan Suparno, S.Pd (sebagai ahli materi) yang telah memberikan masukan nyata dan saran berarti dalam penelitian ini.

\section{DAFTAR PUSTAKA}

[1] A. U. Harahap and F. U. Syahrizal, "Kualifikasi Pengetahuan Dan Keterampilan Pekerja Konstruksi Non-Sertifikasi Berdasarkan SKKNI Pada Proyek Perumahan Di Wilayah Medan," J. Tek. Sipil USU, vol. 6, no. 1, 2017.

[2] R. Arthur and Daryati, "A Need Assessment on Competency Certification of Construction Workers in Indonesia," in KnE Social Sciences, 2019, vol. 3, no. 12, p. 162.

[3] S. Yamu'alim, "Sertifikat Kompetensi Sebagai Standar Kompetensi Kerja," Forum Manaj., vol. 06, no. 1, 2014.

[4] U. Utomo Tegar Adhi, Handayani Fajar S, Sugiyarto, "Strategi Peningkatan Kinerja Tenaga Kerja Proyek Konstruksi dalam Menghadapi Persaingan Masyarakat Ekonomi ASEAN," J. Adm. Publik, vol. 1, no. 2, pp. 131-139, 2011.

[5] I. Hanafi, Pendidikan Teknik dan Vokasional. Bandung: Refika Aditama, 2014.

[6] Rivelino, "Analisis Faktor-faktor yang Mempengaruhi Pelaksanaan Sertifikasi Keterampilan Kerja Tenaga Kerja Terampil Konstruksi," 2017.

[7] C. Yuliana, "Studi Pemahaman dan Penerapan Standard Kompetensi Keterampilan Kerja Tenaga Kerja pada Pelaksanaan Proyek Konstruksi," J. Teknol. Berkelanjutan, vol. I, no. 1, pp. $1-8,2011$.

[8] N. Santiyadnya, "Implementasi Uji Kompetensi dan Pengaruhnya terhadap Kualitas Lulusan SMK Negeri Bidang Teknologi di Provinsi Bali," J. Tek. Elektron., vol. 8, no. 1, pp. 1-16, 2011.

[9] B. Santosa, "Uji Kompetensi Berbasis Kerja di Sekolah Menengah Kejuruan," Pros. Konf. Nas. Ke-7, pp. 135-142, 2018.

[10] T. Rahayu, Purwoko, and Zulkardi, "Pengembangan Instrumen Penilaian dalam Pendidikan Matematika Realistik Indonesia (PMRI)," J. Pendidik. Mat., vol. 2, 2009.

[11] S. R. Barclay and L. A. Wolff, "Exploring the career construction interview for vocational personality assessment," J. Vocat. Behav., vol. 81, no. 3, pp. 370-377, 2012.

[12] K. Setemen and U. P. Ganesha, "Pengembangan dan Pengujian Validitas Butir Instrumen Kecerdasan Logis-Matematis," J. Pendidik. Teknol. dan Kejuru., vol. 15, no. 2, pp. 178-187, 2018.

[13] A. Dardiri, "Analisis Pola, Jenis, dan Penyebab Kerusakan Bangunan Gedung Sekolah Dasar," J. Teknol. dan Kejuru., vol. 35, no. 1, pp. 71-80, 2012.

[14] R. Arthur, "Pembangunan SMK berbasis Infrastruktur berdasarkan Inpres No.9 tahun 2016 dan Nawacita Presiden Republik Indonesia," in KONASPI, 2016, no. VII, pp. 1903-1909.

[15] E. Pascoal, "Pekerjaan Plesteran Dinding Dengan Metode Work Study," J. Tek. Sipil, 2017.

[16] A. A. Mubarok, R. Arthur, and S. Sri Handoyono, "Pengembangan Pembelajaran E - Learning Mata Kuliah PTM/Jalan Raya Pendidikan Vokasional Konstruksi Bangunan Fakultas Teknik 
Universitas Negeri Jakarta," J. Pensil, vol. 7, no. 2, 2018.

[17] N. Puspitasari and S. Haryani, "Pengembangan Rubrik Performance Assessment pada Praktikum Hidrolisis Garam," vol. 8, no. 1, pp. 1250-1259, 2014.

[18] E. T. Suryandari, "Performance Assessment sebagai Instrumen Penilaian Meningkatkan Keterampilan Proses pada Praktikum Kimia," vol. 3, pp. 19-34, 2013.

[19] E. F. Eshun and P. Osei-Poku, "Design Students Perspectives on Assessment Rubric in Studio-Based Learning," J. Univ. Teach. Learn. Pract., vol. 10, 2013.

[20] W. Wati and Novianti, "Pengembangan Rubrik Asesmen Keterampilan Proses Sains pada Pembelajaran IPA SMP," J. Ilm. Pendidik. Fis., 2016.

[21] A. bt A. Rahman, N. binti M. Hanafi, M. bt I. Mukhtar, and J. bin Ahmad, "Assessment Practices for Competency based Education and Training in Vocational College, Malaysia," in International Conference on Education \& Educational Psychology, 2014, vol. 112, no. Iceepsy 2013, pp. 1070-1076.

[22] Menteri Tenaga Kerja dan Transmigrasi, "Nomor 31 Tahun 2014 Standar Kompetensi Kerja Nasional Indonesia - Jabatan Kerja Tukang Bangunan Gedung," 2014.

[23] Kementerian Pendidikan dan Kebudayaan, "KI \& KD SMK/MAK - Kompetensi Keahlian Konstruksi Gedung Sanitasi dan Perawatan,” 2017. 